\title{
Oral lymphoepithelial cyst: A clinicopathological study of 26 cases and review of the literature
}

\author{
Maria Sykara ${ }^{1}$, Panagiotis Ntovas ${ }^{2}$, Eleni-Marina Kalogirou ${ }^{3}$, Konstantinos I. Tosios ${ }^{4}$, Alexandra Sklavounou ${ }^{5}$ \\ ${ }^{1}$ DDS, Faculty of Dentistry, National and Kapodistrian University of Athens, Athens, Greece \\ ${ }^{2}$ DDS, Postgraduate Student, Department of Operative Dentistry, Faculty of Dentistry, National and Kapodistrian University of \\ Athens, Athens, Greece \\ ${ }^{3}$ DDS, MSc, PhD Candidate, Department of Oral Medicine and Pathology, Faculty of Dentistry, National and Kapodistrian Uni- \\ versity of Athens, Athens, Greece \\ ${ }^{4}$ DDS, PhD, Assistant Professor, Department of Oral Medicine and Pathology, Faculty of Dentistry, National and Kapodistrian \\ University of Athens, Athens, Greece \\ ${ }^{5}$ DDS, MSc, PhD, Professor, Department of Oral Medicine and Pathology, Faculty of Dentistry, National and Kapodistrian Uni- \\ versity of Athens, Athens, Greece
}

Correspondence:

Department of Oral Medicine and Pathology

Faculty of Dentistry

National and Kapodistrian University of Athens

2 Thivon Street, 11527 Athens, Greece

eleni_kalogirou@hotmail.com

Sykara M, Ntovas P, Kalogirou EM, Tosios KI, Sklavounou A. Oral lym-
phoepithelial cyst: A clinicopathological study of 26 cases and review of
the literature. J Clin Exp Dent. 2017;9(8):e1035-43.
http://www.medicinaoral.com/odo/volumenes/v9i8/jcedv9i8p1035.pdf

Received: 23/05/2017

Accepted: 28/06/2017

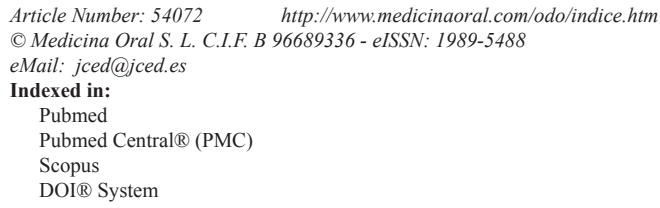

\begin{abstract}
Introduction: To describe the clinicopathological features of 26 oral lymphoepithelial cysts (LECs) and review the literature.

Material and Methods: Twenty-six cases of oral LECs diagnosed during a 37-year period were retrospectively collected. The patients' gender and age, as well as the main clinical features of the cysts were retrieved from the requisition forms. The main microscopic features were recorded after reevaluation of all cases. Pubmed and Google Scholar electronic databases were searched with the key word "oral LEC". Inclusion criteria were the microscopic confirmation of LEC diagnosis and the report at least two of three main clinical features (gender, age and cyst's location).

Results: The 26 oral LECs represented $0.08 \%$ of 31,564 biopsies accessioned during the study period. They affected 25 patients, 14 females and 11 males with a mean age of 33.04 \pm 9.81 years. They appeared as smooth (92\%) nodules, with soft $(24 \%)$ or firm $(76 \%)$ consistency and normal $(28 \%)$, yellow to normal $(20 \%)$, yellow (32\%) or white $(20 \%)$ hue, in the tongue $(69.23 \%)$ or the floor of mouth $(30.77 \%)$. They were covered by parakeratinized squamous $(92.31 \%)$ or non-keratinized (7.69\%) epithelium and contained desquamated epithelial cells, amorphous eosinophilic material and/or inflammatory cells $(100 \%)$. The lymphoid tissue surrounded the cystic cavity partially $(34.62 \%)$ or completely $(65.38 \%)$, often in a follicular pattern with prominent germinal centers $(53.85 \%)$. Literature review yielded 316 cases of oral LECs derived from 25 case reports, 3 case studies/retrospective studies with detailed information for each case and 7 studies with summarized data.
\end{abstract}


Conclusions: Oral LEC is a pathologic entity with discrete clinical presentation that is, however, commonly misdiagnosed in clinical practice as other, mostly benign, entities. Its pathogenesis remains obscure, as its clinicopathologic features are consistent with both theories suggested up to date.

Key words: Oral lymphoepithelial cyst; developmental cyst; non odontogenic cyst; lymphoid tissue; oral tonsil.

\section{Introduction}

The oral lymphoepithelial cyst (LEC) is a rare, soft-tissue, developmental cyst $(1,2)$, first described by Gold (3) in 1962 as "branchial cleft cyst". The name LEC that was in use for the description of branchial cysts of the neck $(4,5)$ was proposed by Bhaskar (6) in 1966. Other names applied were "branchial cleft cyst" $(7,8)$, "branchiogenic cyst" (9) or "tonsillar pseudocyst"(10).

LECs arise in various organs, i.e. pancreas (11), stomach (12), thyroid (13), esophagus (14) and mediastinum (15). In the head and neck area it is most common in the lateral cervical region and the parotid glands, with LECs of major salivary glands associated with the human immunodeficiency virus $(4,16)$. Oral LECs usually present in the floor of mouth or the lateral margin of tongue, as painless nodules of normal-yellow to white color and soft to firm consistency, measuring less than $1 \mathrm{~cm}(17-21)$. Microscopically, the cystic cavity is lined by stratified squamous or/and pseudostratified columnar epithelium and contains desquamated epithelial cells and inflammatory cells. The fibrous connective tissue wall of the cyst is surrounded by lymphoid tissue, usually with a follicular pattern $(6,17,18,20)$. The pathogenesis of intraoral LEC has not been settled $(3,10,22)$.

The objective of the present study is to describe the clinicopathological features of 26 oral LECs and review the pertinent literature with emphasis on its histopathogenesis.

\section{Material and Methods}

All cases of LEC diagnosed in the pathology laboratory of the Department of Oral Medicine and Pathology between 1980 and 2016 were retrospectively collected. LECs of the major salivary glands were excluded. Patients' gender and age, location, clinical features (color, consistency, surface texture and maximum dimension), symptoms and duration of the lesion before diagnosis, as well as clinical diagnosis were collected from the requisition forms. The main clinical features of the cases studied are summarized in table 1 . The histopathological features studied were type of the lining epithelium, cystic content, pattern of lymphoid tissue, type of adjacent anatomic structures and overlying mucosa. All patients at the time of their initial examination gave written consent for the future use of their data for study. The study was approved by the Research Ethics Committee (NKUOA code number 310).
Pubmed and Google Scholar electronic databases were searched on April 2017 with the key word "oral lymphoepithelial cyst" and the pertinent literature was collected. Studies included were those where the diagnosis had been confirmed by microscopic examination and at least two of three main clinical features (gender, age and location of the cyst) were reported. Cases located on the palatine tonsils, oropharynx or jawbones were excluded from evaluation.

\section{Results}

-Demographics

Twenty six oral LECs in 25 patients were found (a 32year-old woman presented two adjacent intraoral LECs) among 31,564 biopsies accessioned during the study period, representing $0.08 \%$. Fourteen patients were females (56\%) and 11 males (44\%), with a female to male ratio of 1:0.79. Age was known in 23 patients and ranged from 15 to 51 years (mean age $=33.04 \pm 9.81$ years). Most LECs were found in adults in 3rd (39.13\%), 4th $(26.09 \%)$ or 5 th $(26.09 \%)$ decade of life, only 1 case considered an adolescent.

\section{-Clinical features}

LECs appeared as nodules, covered by normal (28\%), yellow to normal $(20 \%)$, yellow (32\%) or white $(20 \%)$ mucosa. The surface was smooth (92\%) and rarely ulcerated $(4 \%)$ or granular (4\%). Consistency was reported as soft (24\%) or firm (76\%). Clinical information was missing in one case. The majority of lesions (18 cases, $78.26 \%$ ) measured less than $1 \mathrm{~cm}$ in greatest dimension (range $=0.3$ $1.7 \mathrm{~cm}$, mean dimension $=0.69 \pm 0.3 \mathrm{~cm}$ ). Most LECs were located on the tongue (18 cases, $69.23 \%$ ), in particular the ventral surface ( 9 cases, $50 \%$ ), the lateral margins ( 8 cases, $44.44 \%$, Fig. 1A), or the tip (1 case, $5.56 \%$ ), followed by the floor of mouth ( 8 cases, $30.77 \%$, Fig. 1B). The two adjacent lesions in a 32-year-old female were located on the posterior lateral margin of the tongue and were clinically identical.

Twenty LECs were noticed 2 days to 5 years before biopsy and 16 of them (80\%) were excised during the first year. Oral LEC was the most common clinical diagnosis, reported in almost half of cases (11/26, 42.3\%). Other clinical diagnoses included lipoma, mucous extravasation cyst (mucocele), irritation fibroma, squamous papilloma, hyperplastic foliate papilla, ectopic lymphoglandular tissue and minor salivary gland. All lesions were asymptomatic and surgically excised under local 
Table 1: Demographics and clinical characteristics of the 26 oral lymphoepithelial cysts.

\begin{tabular}{|c|c|c|c|c|c|c|c|c|c|}
\hline $\begin{array}{l}\text { Case } \\
\text { No. }\end{array}$ & Sex & Age* & Site & Color & Surface & Cons & $\begin{array}{c}\text { Max } \\
\operatorname{dim}^{* *}\end{array}$ & Duration & $\begin{array}{c}\text { Provisional clinical } \\
\text { diagnosis }\end{array}$ \\
\hline 1 & $\mathrm{M}$ & 28 & FOM & normal & smooth & firm & 1 & 3 years & mucocele \\
\hline 2 & $\mathrm{~F}$ & 28 & T-tip & white & smooth & soft & 0.5 & $\mathrm{~N} / \mathrm{A}$ & irritation fibroma \\
\hline 3 & $\mathrm{~F}$ & 29 & T-LM & yellow & smooth & firm & 0.5 & 4 months & LEC \\
\hline 4 & $\mathrm{~F}$ & 32 & T-LM & $\begin{array}{l}\text { yellow- } \\
\text { normal }\end{array}$ & smooth & firm & 1 & 2 months & LEC, ELT \\
\hline 5 & $\mathrm{~F}$ & 32 & T-LM & $\begin{array}{l}\text { yellow- } \\
\text { normal }\end{array}$ & smooth & firm & 1 & 2 months & LEC, ELT \\
\hline 6 & $\mathrm{M}$ & 35 & T-VS & $\begin{array}{l}\text { yellow- } \\
\text { normal }\end{array}$ & smooth & firm & 0.7 & 5 years & LEC \\
\hline 7 & $\mathrm{M}$ & 48 & FOM & yellow & smooth & firm & 0.5 & N/A & LEC, lipoma \\
\hline 8 & $\mathrm{~F}$ & 43 & T-LM & yellow & smooth & soft & 0.7 & 20 days & LEC \\
\hline 9 & $\mathrm{M}$ & 43 & T-VS & normal & smooth & firm & 0.5 & $>1$ year & $\begin{array}{l}\text { mucocele, irritation } \\
\text { fibroma }\end{array}$ \\
\hline 10 & $\mathrm{~F}$ & 24 & FOM & yellow & smooth & firm & 0.6 & N/A & lipoma \\
\hline 11 & $\mathrm{M}$ & 51 & T-LM & yellow & smooth & firm & 1.7 & 2 days & LEC, lipoma \\
\hline 12 & $\mathrm{M}$ & 20 & T-VS & normal & smooth & soft & 0.8 & 6 months & mucocele \\
\hline 13 & $F$ & 29 & T-LM & white & smooth & firm & 0.5 & N/A & LEC, lipoma \\
\hline 14 & $\mathrm{~F}$ & 24 & T-LM & white & ulcerated & firm & 0.6 & 5 months & irritation fibroma \\
\hline 15 & $\mathrm{M}$ & N/A & FOM & normal & smooth & firm & 0.5 & N/A & lipoma \\
\hline 16 & $\mathrm{M}$ & $\mathrm{N} / \mathrm{A}$ & T-VS & yellow & smooth & firm & 0.8 & 1 year & LEC, lipoma \\
\hline 17 & $\mathrm{~F}$ & 15 & FOM & yellow & smooth & firm & 0.5 & 8 months & $\begin{array}{l}\text { MSG, lipoma, } \\
\text { irritation fibroma }\end{array}$ \\
\hline 18 & $\mathrm{~F}$ & 43 & T-LM & normal & granular & firm & 1 & 1 month & $\begin{array}{c}\text { irritation fibroma, } \\
\text { papilloma }\end{array}$ \\
\hline 19 & $\mathrm{~F}$ & 37 & T-VS & normal & smooth & firm & 0.5 & 5 days & mucocele \\
\hline 20 & $\mathrm{~F}$ & 22 & T-VS & yellow & smooth & firm & 0.5 & 3 months & $\mathrm{N} / \mathrm{A}$ \\
\hline 21 & $\mathrm{M}$ & 37 & FOM & white & smooth & soft & N/A & 3 months & HFP \\
\hline 22 & $\mathrm{~F}$ & 45 & FOM & white & smooth & soft & 0.3 & N/A & irritation fibroma \\
\hline 23 & $\mathrm{~F}$ & 32 & T-VS & $\begin{array}{l}\text { yellow- } \\
\text { normal }\end{array}$ & smooth & soft & 0.5 & 6 months & LEC \\
\hline 24 & $\mathrm{M}$ & 30 & FOM & N/A & $\mathrm{N} / \mathrm{A}$ & $\mathrm{N} / \mathrm{A}$ & N/A & 6 months & mucocele \\
\hline 25 & $\mathrm{M}$ & 22 & T-VS & $\begin{array}{l}\text { yellow- } \\
\text { normal }\end{array}$ & smooth & firm & 0.6 & 1 month & mucocele, lipoma \\
\hline 26 & $\mathrm{~F}$ & 43 & T-VS & normal & smooth & firm & N/A & 1 month & LEC \\
\hline
\end{tabular}

$*_{\text {in years, }}^{* * \text { in } \mathrm{cm}}$

Abbreviations: Cons, consistency; Max dim, maximum dimension in N/A, not available; FOM , floor of mouth; T-tip, tip of tongue; T-LM, lateral margin of tongue; T-VS, ventral surface of tongue; LEC, lymphoepithelial cyst; ELT, ectopic lymphoglandular tissue; MSG, minor salivary gland; HFP, hyperplastic foliate papilla.

anesthesia.

-Histopathological features

Table 2 summarizes the main histopathological data of the cases studied. The two adjacent LECs showed similar histopathological features (fig. 2A). In 24 cases (92.31\%) the cystic epithelium was parakeratinized and in 17 of them (70.83\%) prominent hyperplasia of the parakeratin layer was noticed (fig. 2B). In one of those cases transition from squamous to pseudostratified columnar epithelium was also seen. In $2 / 26$ cases $(7.69 \%)$ the cyst was lined by non-keratinized squamous epithelium with a superficial layer of cuboidal cells. Mucous cells 


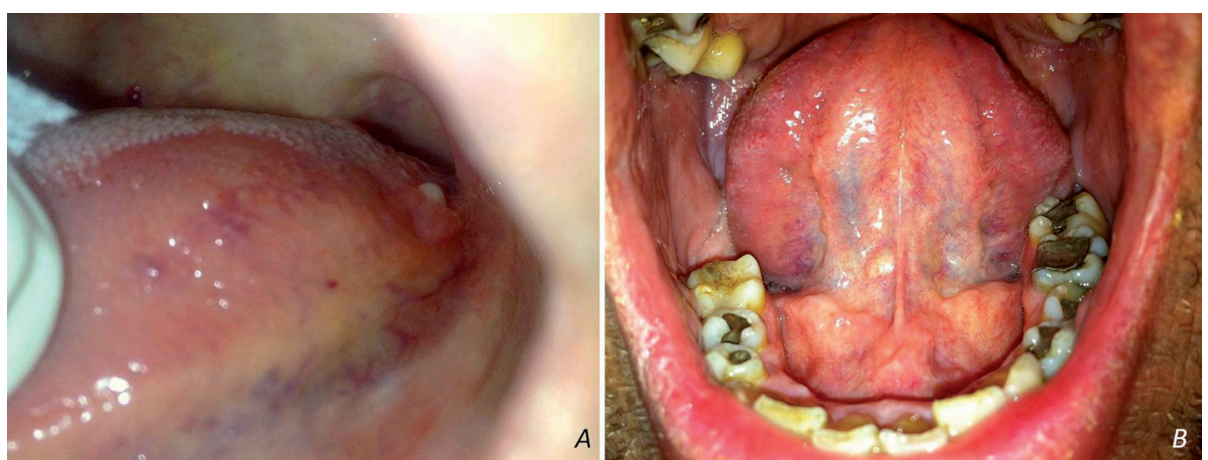

Fig. 1: Yellow-white nodules on the posterior lateral margin of the tongue (A) and floor of mouth (B).

Table 2: Histopathological features of the 26 oral lymphoepithelial cysts.

\begin{tabular}{|l|c|}
\hline Feature & $\mathrm{n}(\%)$ \\
\hline Cystic epithelium & \\
\hline parakeratinized stratified squamous epithelium & $24 / 26(92.31 \%)$ \\
\hline hyperplasia of parakeratin layer & $17 / 24(70.83 \%)$ \\
\hline transition from squamous to pseudostratified columnar epithelium & $1 / 24(4.17)$ \\
\hline non keratinized (cuboidal) epithelium & $2 / 26(7.69 \%)$ \\
\hline Cystic lumen & \\
\hline desquamated keratinocytes, amorphous eosinophilic material, polymorphonuclear & $26 / 26(100 \%)$ \\
\hline leukocytes, lymphocytes and plasma cells & \\
\hline Lymphoid tissue & $17 / 26(65.38 \%)$ \\
\hline completely surrounding the cystic lumen & $9 / 26(34.62 \%)$ \\
\hline partially surrounding the cystic lumen & $14 / 26(53.85 \%)$ \\
\hline follicular pattern with prominent germinal centers & \\
\hline Adjacent anatomic structures in the cystic wall & $1 / 26(3.85 \%)$ \\
\hline epithelial islands & $6 / 26(23.08 \%)$ \\
\hline acinar or/and ducts of minor salivary glands & \\
\hline Overlying mucosa & $22 / 26(84.62 \%)$ \\
\hline present & $22 / 22(100 \%)$ \\
\hline parakeratinized, stratified squamous epithelium & $1 / 22(4.55 \%)$ \\
\hline continuity between the cystic wall and the overlying mucosa & $10 / 22(45.45 \%)$ \\
\hline cyst directly beneath the oral mucosa & $4 / 26(15.38 \%)$ \\
\hline absent & \\
\hline & \\
\hline
\end{tabular}

or goblet cells were not found. The inflammatory cells infiltrated focally the cystic epithelium in most cases. The lymphoid tissue surrounded the cystic cavity partially ( 9 cases, $34.62 \%$ ) or completely (17 cases, $65.38 \%$ ) and was arranged in a follicular pattern with prominent germinal centers (14 cases, $53.85 \%$, Fig. 3A,B). The cystic lumen in all cases was filled with desquamated epithelial cells, amorphous eosinophilic material and/or polymorphonuclear leukocytes, lymphocytes and plasma cells (Fig. 3A,B). The cystic wall consisted of non inflammatory, loose to dense fibrous connective tissue and exhibited areas of epithelial islands and minor salivary glands in one and six cases, respectively.

The overlying mucosa was present in the histopathological sections of 22 cases $(84.62 \%)$ and was covered by parakeratinized, stratified squamous epithelium. In 10 cases the cyst was located directly beneath the oral mucosa. Continuity of the cystic epithelium and the overlying mucosa was noticed in one case.

-Literature review 


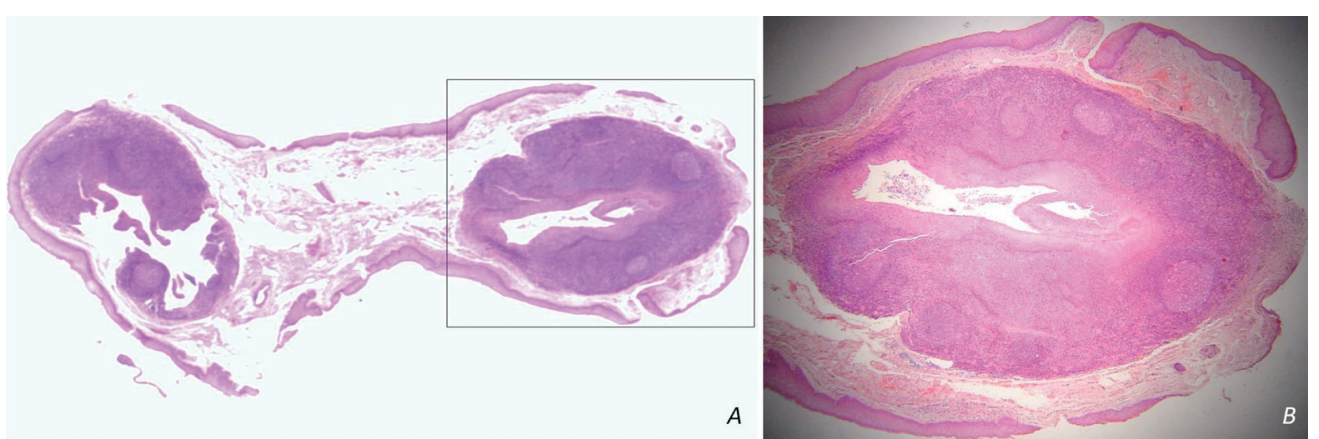

Fig. 2: A) Two adjacent LECs from the lateral lingual margin with similar histopathological features. B) The cystic cavity is lined by parakeratinized stratified squamous epithelium with prominent hyperplasia of the parakeratin layer [hematoxylin and eosin stain; original magnifications (A) x1, (B) x25].

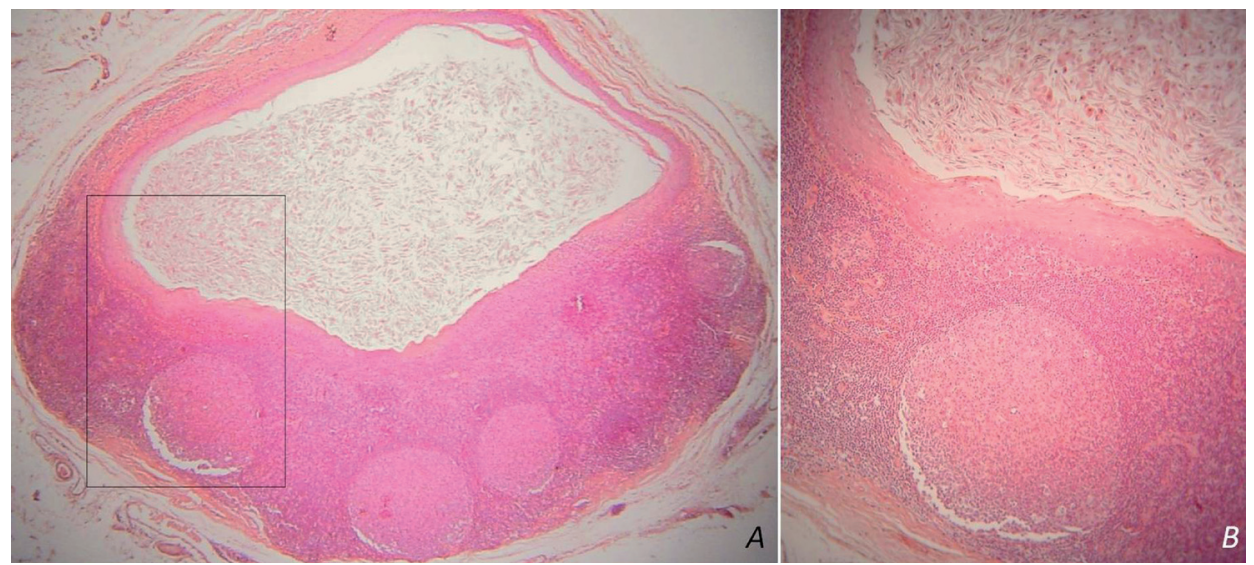

Fig. 3: Lymphoid tissue surrounds the cystic cavity in a follicular pattern with prominent germinal centers. The cystic lumen contains desquamated epithelial cells, amorphous eosinophilic material and inflammatory cells [hematoxylin and eosin stain; original magnifications (A) x25, (B) x100].

Forty-five papers were retrieved; 10 case-reports were excluded, 7 due to inability to access full-text (23-29) and 3 due to non-intraoral location (30-32). Only two cases from a report of multiple LECs in the same patient (33) were included, as the rest lacked histopathological confirmation, while for the same reason another case (34) included in previous reviews $(35,36)$ was omitted. In total our review included 316 cases of oral LEC (Table 3 ) derived from 25 case reports $(3,7-9,19,21,22,33,35,37-$ $52), 3$ short case studies/retrospective studies $(17,20,53)$ with detailed information for each case, as well as 7 studies $(1,2,6,10,18,36,54)$ with summarized sample data. In three of the latter studies $(1,2,36)$ there were 8 cases in the palatine tonsil or the oropharynx that could not be excluded, due to the way the data were reported.

\section{Discussion}

The 26 LEC cases presented herein represent less than $0.1 \%$ of all biopsies accessioned in a single oral pathology laboratory during a 37 -year period, while in two previous studies they respective figures were $0.11 \%$ in
53 years (2) and $0.1 \%$ in 40 years (1). The asymptomatic nature of LECs that make their recognition mostly an incidental finding $(3,9,19,39,49)$, as well as their clinical misdiagnosis as normal anatomic structures, e.g. foliate papillae (53) may account for the rarity of recorded cases.

In this study oral LEC showed a slight female predilection (female to male ratio 1:0.79), while in 316 previously reported cases (table 3 ) there is considerable no predilection (female to male ratio 1:0.9). Previously reported oral LECs showed a broad age distribution (2-81 years), but they were more common in 3rd to 5 th decades of life $(1,2,6,18,20,36,54)$, which is in accordance to the present study. Children and adolescents are rarely affected, with approximately 14 cases reported $(1,2,6,7,10,18,20,36,40,50,54)$, while there is a unique case of oral LECs in a mother and her daughter (20).

Lingual LECs represented more than two thirds of the cases presented herein, with the remaining cases located on the floor of mouth. In contrast, among 316 cases included in our review (Table 3), more cases $(n=160$, 
Table 3: Review of the demographical features, location, maximum dimension and duration of 316 previously reported cases of oral LEC.

\begin{tabular}{|c|c|c|c|c|}
\hline Reference & $\begin{array}{l}\text { LEC } \\
\text { Cases }\end{array}$ & Sex & Age (mean)* & Site \\
\hline Gold (3) & 1 & $\mathrm{M}$ & 32 & FOM \\
\hline Calman (9) & 1 & $\mathrm{M}$ & 40 & FOM \\
\hline Vickers et al. (22) & 1 & $\mathrm{M}$ & 31 & FOM \\
\hline Bhaskar (6) & 24 & $17 \mathrm{M}, 7 \mathrm{~F}$ & $15-65(36.4)$ & $15 \mathrm{FOM}, 8 \mathrm{~T}, 1 \mathrm{PF}$ \\
\hline Young \& Claman (52) & 1 & $\mathrm{M}$ & 42 & FOM \\
\hline Robins (7) & 1 & $\mathrm{~F}$ & 4 & FOM \\
\hline \multirow[t]{2}{*}{ Doyle et al. (8) } & \multirow[t]{2}{*}{2} & $\mathrm{M}$ & 48 & FOM \\
\hline & & $\mathrm{F}$ & 20 & FOM \\
\hline Knapp (10) & 13 & $\geq 12 \mathrm{M}$ & NA & 7 FOM, 4 SP, 2 T-VS \\
\hline Acevedo \& Nelson (17) & 9 & $9 \mathrm{M}$ & $20-46(27.6)$ & 9FOM \\
\hline Merchart (44) & 1 & $\mathrm{M}$ & 22 & FOM \\
\hline Giunta \& Cataldo (20) & 21 & $9 \mathrm{M}, 12 \mathrm{~F}$ & $\begin{array}{c}\text { 7-65 (32.6) } \\
3 \text { NA }\end{array}$ & $\begin{array}{c}17 \text { FOM, } 2 \text { SP, } 1 \text { LM, } 1 \\
\text { retromolar area }\end{array}$ \\
\hline Buchner \& Hansen (18) & 38 & $23 \mathrm{M}, 15 \mathrm{~F}$ & $14-81(39.8)$ & $\begin{array}{c}\text { 19 FOM, } 7 \text { T-VS, } 7 \text { T-LM, } 2 \text { SP, } 2 \\
\text { HP, } 1 \text { BM }\end{array}$ \\
\hline Toto et al. (53) & 6 & $3 \mathrm{M}, 3 \mathrm{~F}$ & $\begin{array}{c}25-60(43.2) \\
1 \text { NA }\end{array}$ & 2 FOM, 3 T-LM, 1 T-VS, 1 SP \\
\hline Sakoda et al. (46) & 1 & $\mathrm{~F}$ & 19 & T-VS \\
\hline Chaundhry et al. (54) & 24 & $9 \mathrm{M}, 15 \mathrm{~F}$ & $12-74(39.5)$ & $24 \mathrm{FOM}$ \\
\hline Iwase et al. (42) & 1 & $\mathrm{M}$ & 34 & FOM \\
\hline Yamamoto et al. (51) & 1 & $\mathrm{~F}$ & 43 & T-VS \\
\hline Kumara et al. (43) & 1 & $\mathrm{M}$ & 29 & FOM \\
\hline Ahn et al. (37) & 1 & $\mathrm{~F}$ & 56 & FOM \\
\hline Flaitz (40) & 1 & $\mathrm{M}$ & 4 & FOM \\
\hline Suzuki et al. (35) & 1 & $\mathrm{M}$ & 30 & T-VS \\
\hline Flaitz \& Davis (41) & 1 & $\mathrm{M}$ & 72 & T-LM \\
\hline Epivatianos et al. (19) & 1 & $\mathrm{M}$ & 27 & FOM \\
\hline Pereira et al. (45) & 1 & $\mathrm{~F}$ & 46 & T-LM \\
\hline Khelemsky \& Mandel (21) & 1 & $\mathrm{M}$ & 34 & FOM \\
\hline Costa et al. (38) & 1 & $\mathrm{M}$ & 71 & T-VS \\
\hline Silva et al. (48) & 1 & $\mathrm{M}$ & 71 & $\mathrm{BM}$ \\
\hline Nonaka et al. (1) & 10 & $2 \mathrm{M}, 8 \mathrm{~F}$ & $16-60(39.8)$ & $\begin{array}{c}2 \text { FOM, } 4 \text { T, } 1 \text { palate, } 2 \\
\text { oropharynx***, } 1 \text { NA }\end{array}$ \\
\hline Vieira et al. (50) & 1 & $\mathrm{M}$ & 16 & $\mathrm{PF}$ \\
\hline \multirow{2}{*}{$\begin{array}{l}\text { Stramandinoli-Zanicotti et al. } \\
\text { (49) }\end{array}$} & \multirow[t]{2}{*}{2} & $\mathrm{~F}$ & 57 & FOM \\
\hline & & $\mathrm{F}$ & 55 & T-LM \\
\hline Yang et al. (36) & 120 & $37 \mathrm{M}, 83 \mathrm{~F}$ & $2-75(44.1)$ & $\begin{array}{c}\text { 46 FOM, } 41 \text { T-VS, } 11 \text { T-base, } 7 \\
\text { T-LM, } 1 \text { T-dorsum, } 3 \text { HP, } 3 \text { SP, } 3 \\
\text { BM, } 2 \text { glossodesmus, } 3 \\
\text { oropharynx *** }\end{array}$ \\
\hline
\end{tabular}


Table 3 continue: Review of the demographical features, location, maximum dimension and duration of 316 previously reported cases of oral LEC.

\begin{tabular}{|c|c|c|c|c|}
\hline \multirow[t]{2}{*}{ Chaves (33) } & \multirow[t]{2}{*}{2} & \multirow[t]{2}{*}{$\mathrm{F}$} & \multirow[t]{2}{*}{42} & T-VS \\
\hline & & & & T-VS \\
\hline \multirow[t]{2}{*}{ Silva et al. (47) } & \multirow[t]{2}{*}{2} & \multirow[t]{2}{*}{$\mathrm{F}$} & \multirow[t]{2}{*}{ NA } & T-LM (right) \\
\hline & & & & T-LM (left) \\
\hline Uchoa-Vasconcelos et al. (2) & 22 & $10 \mathrm{M}, 12 \mathrm{~F}$ & $14-69(44.09)$ & $\begin{array}{l}4 \mathrm{FOM}, 11 \mathrm{~T}, 2 \mathrm{BM}, 1 \mathrm{LM}, 1 \mathrm{SP}, \\
2 \text { palatine tonsil, } 1 \text { oropharynx*** }\end{array}$ \\
\hline de Sousa et al. (39) & 1 & $\mathrm{~F}$ & 53 & T-VS \\
\hline
\end{tabular}

$*$ in years, $* *$ in $\mathrm{cm}$

*** In these studies there were 8 cases in the palatine tonsil or the oropharynx that could not be excluded, due to the way the data were reported.

***Abbreviations: LEC, lymphoepithelial cyst; Max dim, maximum dimension; N/A, not available; FOM, floor of mouth; T, tongue; T-LM, lateral margin of tongue; T-VS, ventral surface of tongue; T-base, base of tongue; T-dorsum, dorsum of tongue; PF, palatoglossal fold; SP, soft palate; HP, hard palate; BM, buccal mucosa, LM; labial mucosa.

$50.63 \%$ ) were located in the floor of mouth compared to the tongue ( $\mathrm{n}=114,36.08 \%)$, followed in descending order by the soft palate, buccal mucosa, hard palate, labial mucosa, palatoglossal fold, glossodesmus and retromolar area. There is no other report of two clinically identical, adjacent LECs, while there are some scarce reports of multiple LECs in the same patient $(33,47)$. The coexistence of oral LEC with an epithelial inclusion cyst has been also reported $(19,37)$.

Oral LEC manifested as a soft to firm, well defined submucosal nodule, covered by mucosa with normal, yellow or white hue, as in most previous studies (9,10,17-19$21,22,33,35-38,40,42,45,46,48-51)$. The yellowish color has been attributed to the keratin or the purulent content that is commonly found within the cyst's lumen $(10,20)$. Oral LECs with transparent, translucent, purple or gray hue have been rarely recorded $(17,36)$. The surface of LEC is generally smooth $(3,9,19,21,22,33,37,39,40,45,4$ $6,48-50,52)$, but may be ulcerated (35) as seen in one of our cases, probably due to secondary trauma. They are predominantly less than $1 \mathrm{~cm}(6,17-21,33,35,36,38,39,42$, $45,46,48,49,51,52)$, may be present for several days to years $(2,6,7,17-19,21,35-37,40,42,46,50,51,53)$ and are generally painless $(3,9,17-22,33,36-39,42,45,46,49-52)$. Symptoms, such as pain or discomfort in swallowing may be occasionally reported, for example in case of large (7) or ulcerated (35) lesions.

In most cases LECs are clinically misdiagnosed as mucus cyst $(9,18-20,36,37,46,48,51-53)$, with the list of clinical diagnoses also including normal anatomic structures, such as foliate papilla, sebaceous gland, sublingual gland or lymphoid tissue $(18,20,36,50,53)$, as well as pathological entities, including lipoma, fibroma, inflammatory fibrous hyperplasia, squamous papilloma, granular cell tumor, dermoid cyst, inclusion cyst, abscess, sialolithiasis, sialadenitis, nevus and leukoplakia $(8,18,20,35,36,38,48-50,53)$. The high accuracy of clini- cal diagnosis in the present study may be associated with the location of all cases in typical anatomical sites, e.g. tongue and floor of mouth.

The microscopic features of LEC are described is studies performed more than three decades ago $(6,10,17,18,20,53)$. The sample size of the present case series is the largest, after the study by Buchner and Hansen (18) published 37 years ago. Oral LECs are predominantly lined by thin $(7,9,18,20,50)$, parakeratinized stratified squamous epithelium $(6,17-20,33,35,37-40,42,45,46,49,51,53)$, with flattened rete pegs $(3,6,9,17-19,21,22,35,39,46,48,50,52)$, probably due to the pressure exerted by the surrounding lymphoid tissue (35). The lining epithelium may be, also, orthokeratinized (18) or non-keratinized $(22,52)$ stratified squamous, pseudostratified columnar $(7,18,20,48,50)$ or ciliated columnar (20), and contain mucous/goblet cells $(18,20,40)$. It is, occasionally, infiltrated by lymphocytes or polymorphonuclear leukocytes $(7,9,42,50,52)$. The cystic cavity is occupied by desquamated epithelial cells, keratin or amorphous eosinophilic material, and inflammatory cells $(6,9,10,17-21,35,37,42,46,49,51,53)$. The lymphoid tissue surrounds the entire cyst or part of it $(18,20,42)$, often in a follicular arrangement with prominent germinal centers $(3,6,18-22,33,37,40,42,45$, 49,50,52). Epithelial islands (6,17), mucous glands or duct-likes structures $(6,18,21,46)$, microorganisms $(18,53)$ and calcified material $(18)$ may be seen in the lymphoid aggregates or the surrounding fibrous connective tissue. Most of those features were seen in our cases, where the lining epithelium was predominantly hyperparakeratinized stratified squamous.

Considering the pathogenesis of oral LECs, there are two competing theories. The theory of embryologic entrapment or epithelium enclavement supports that epithelium becomes entrapped in the oral mucosal lymphoid tissue and following proliferation due to trauma or chronic inflammation forms the cyst $(3,6,22)$. The entrapped 
epithelium may be remnants of the branchial arches that are found in the floor of mouth, a common localization of LEC (3). According to this theory LEC is a developmental lesion, but this is not consistent with the wide age distribution of oral LEC (46). The epithelium may also originate from the oral mucosal (22) or the salivary ducts $(6,22)$, as epithelial islands and duct-like structures may be identified within the lymphoid tissue or in close proximity with it $(6,17,18,21,46)$ and may undergo cystic changes (6). The presence of columnar epithelial lining observed in several LECs and the continuity of the cystic epithelium with salivary gland ducts favor the latter hypothesis $(20,21,53)$. In support of this theory is also the finding of in vitro studies, where surgical transplantation of buccal epithelium in lymph nodes of hamsters induced the formation of cysts (55).

According to the obstruction theory, a traumatic event or a microbial invasion accompanied by inflammatory reaction may stimulate the parakeratinization of the crypt's non keratinized epithelium $(17,18,20,36)$. With incomplete desquamation, the parakeratinized squamous epithelial cells along with bacteria and purulent material accumulate and obstruct the crypt's orifice, resulting in the formation of LEC (10,18-20). According to this theory, LEC is a pseudocyst LEC. This theory is supported by the most common presence of oral lymphoid tissue ("oral tonsils") in the floor of mouth, tongue and soft palate (10), i.e. the three most frequent sites of intraoral; the presence of inflammatory infiltration of the LEC epithelium; and the continuity or the close proximity of the cystic epithelium with the superficial oral mucosa $(19,21,46,53)$. Continuity, though, may disappear in advanced developmental stages of oral LEC (18) or may not be detected in sections evaluated; thus, lack of it does not necessarily reject the latter theory (53). There are cases, however, where pathogenesis in not consistent with either hypothesis (18) or consistent with both hypothesis (19). As in previous reports, the findings of our study may be interpreted by both theories.

Excisional biopsy is usually recommended to confirm the diagnosis of oral LEC. Recurrence has not been reported in a follow up period up to 17 years (36).

In conclusion, oral LEC is a pathologic entity with discrete clinical presentation that is, however, commonly misdiagnosed in clinical practice as other, mostly benign, entities. Its pathogenesis remains obscure, as its clinicopathologic features are consistent with both theories suggested up to date.

\section{References}

1. Nonaka CF, Henriques AC, de Matos FR, de Souza LB, Pinto LP. Nonodontogenic cysts of the oral and maxillofacial region: demographic profile in a Brazilian population over a 40 -year period. Eur Arch Otorhinolaryngol. 2011;268:917-22.

2. Uchoa-Vasconcelos AC, Filizola-de Oliveira DJ, Roman-Martelli SJ, Etges A, Neutzling-Gomes AP, Chaves-Tarquinio SB. Demogra- phic profile of oral nonodontogenic cysts in a Brazilian population. Med Oral Patol Oral Cir Bucal. 2014;19:308-12.

3. Gold C. Branchial cleft cyst located in the floor of the mouth. Report of a case. Oral Surg Oral Med Oral Pathol. 1962;15:1118-20.

4. Bhaskar SN, Bernier JL. Histogenesis of branchial cysts; a report of 468 cases. Am J Pathol. 1959;35:407-43.

5. King ESJ. The Lateral Lymphoepithelial Cyst of the Neck (Branchial Cyst). Aust New Zeal J Surg. 1949;29:109-21.

6. Bhaskar SN. Lymphoepithelial cysts of the oral cavity. Report of twenty-four cases. Oral Surg Oral Med Oral Pathol. 1966;21:120-8.

7. Robins RB. Sublingual branchial cleft cyst: a case report. Laryngoscope. 1969;79:288-94.

8. Doyle JL, Weisinger E, Manhold JH Jr. Benign lymphoid lesions of the oral mucosa. Preliminary classification. Oral Surg Oral Med Oral Pathol. 1970;29:31-7.

9. Calman HI. Sublingual branchiogenic cyst. Report of a case. Oral Surg Oral Med Oral Pathol. 1963;16:333-8.

10. Knapp MJ. Pathology of oral tonsils. Oral Surg Oral Med Oral Pathol. 1970;29:295-304.

11. Mege D, Gregoire E, Barbier L, Del Grande J, Le Treut YP. Lymphoepithelial cyst of the pancreas: an analysis of 117 patients. Pancreas. 2014;43:987-95.

12. Delvaux S, Ectors N, Geboes K, Desmet V. Gastric gland heterotopia with extensive lymphoid stroma: a gastric lymphoepithelial cyst. Am J Gastroenterol. 1996;91:599-601.

13. Choi CJ, Choi SW, Cho JG, Woo JS. Bilateral lymphoepithelial cysts of the thyroid gland. Thyroid. 2010;20:111-3.

14. Asami S, Naomoto Y, Yamatsuji T, Shirakawa Y, Murata T, Kobayashi M, et al. Lymphoepithelial cyst of the cervical esophagus. J Gastroenterol. 2006;41:88-9.

15. Ulku R, Yilmaz F, Eren S, Onat S. Lymphoepithelial cyst of the mediastinum. Tex Heart Inst J. 2005;32:440-1.

16. Sujatha D, Babitha K, Prasad RS, Pai A. Parotid lymphoepithelial cysts in human immunodeficiency virus: a review. J Laryngol Otol. 2013;127:1046-9.

17. Acevedo A, Nelson JF. Lymphoepithelial cysts of the oral cavity. Report of nine cases. Oral Surg Oral Med Oral Pathol. 1971;31:632-6.

18. Buchner A, Hansen LS. Lymphoepithelial cysts of the oral cavity. A clinicopathologic study of thirty-eight cases. Oral Surg Oral Med Oral Pathol. 1980;50:441-9.

19. Epivatianos A, Zaraboukas T, Antoniades D. Coexistence of lymphoepithelial and epidermoid cysts on the floor of the mouth: report of a case. Oral Dis. 2005;11:330-3.

20. Giunta J, Cataldo E. Lymphoepithelial cysts of the oral mucosa. Oral Surg Oral Med Oral Pathol. 1973;35:77-84.

21. Khelemsky R, Mandel L. Lymphoepithelial cyst of mouth floor. J Oral Maxillofac Surg. 2010;68:3055-7.

22. Vickers RA, Gorlin RJ, Smart EA. Lymphoepithelial Lesions of the Oral Cavity. Report of Four Cases. Oral Surg Oral Med Oral Pathol. 1963;16:1214-22.

23. Alpaslan G, Oygur T, Saracgil S. Lymphoepithelial cyst. J Marmara Univ Dent Fac. 1993;1:333-6.

24. Cataldo E, Santis HR. A clinico-pathologic presentation. Lymphoepithelial cyst. J Mass Dent Soc. 1985;34:56.

25. Chu C, Aguirre A, Hatton M. AAOMP case challenge: Yellow papule on the ventral tongue. Lymphoepithelial cyst. J Contemp Dent Pract. 2010;11:092-5.

26. Fantasia JE, Damm DD. Yellow nodule of floor of mouth. Lymphoepithelial cyst. Gen Dent. 2001;49:36, 100.

27. Gallagher G, Kabani S, Noonan V. Oral lymphoepithelial cyst. J Mass Dent Soc. 2006;54:52.

28. Haring JI. Case 6. Lymphoepithelial cyst. RDH. 1995;15:11, 35.

29. Hupin C, Weynand B, Rombaux P. Lymphoepithelial cyst of the nasogenian sulcus: a case report. B-ENT. 2010;6:49-51.

30. Bingol F, Balta H, Bingol BO, Mazlumoglu RM, Kilic K. Lymphoepithelial Cyst in the Palatine Tonsil. Case Rep Otolaryngol. 2016;2016:1-3.

31. Castro JG, Ferreira GM, Mendonca EF, Castro LA. A rare occurren- 
ce of lymphoepithelial cyst in the palatine tonsil: a case report and discussion of the etiopathogenesis. Int J Clin Exp Pathol. 2015;8:4264-8. 32. Friedrich RE, Scheuer HA, Fuhrmann A, Zustin J. Bilateral intraosseous lymphoepithelial cyst of the mandible. In Vivo. 2011;25:451-4. 33. Chaves FN, Feitosa SG, Pereira KM, Costa FW. Multiple lymphoepithelial cysts from oral mucosa of a healthy woman: case report and literature review. Indian J Pathol Microbiol. 2013;56:473-4.

34. McDonnell D. Spontaneous regression of a yellow sublingual swelling: a case report. Pediatr Dent. 1990;12:388-9.

35. Suzuki H.; Baba S.; HK. Lymphoepithelial Cyst in the Sublingual Region: Report of a case and review of literature. Oral Medicine \& Pathology. 2000;5:105-8.

36. Yang X, Ow A, Zhang CP, Wang LZ, Yang WJ, Hu YJ, et al. Clinical analysis of 120 cases of intraoral lymphoepithelial cyst. Oral Surg Oral Med Oral Pathol Oral Radiol. 2012;113:448-52.

37. Ahn SK, Won JH, Lee SH, Choi EH, Choi SI. Lymphoepithelial cyst associated with epithelial inclusion cyst. Am J Dermatopathol. 1996;18:424-6.

38. Costa FW, Pereira KM, Viana TS, Cavalcante RB, Nogueira AS. Simultaneous occurrence of a rare lymphoepithelial cyst and squamous cell carcinoma in the oral cavity. Braz J Otorhinolaryngol. 2011;77:270.

39. de Sousa LM, Albuquerque AF, Silva PG, Bezerra TM, Luna EC, Chaves FN, et al. Unusual Occurrence of Tongue Sensorial Disorder after Conservative Surgical Treatment of Lymphoepithelial Cyst. Case Rep Dent. 2015;2015:1-6.

40. Flaitz CM. Oral lymphoepithelial cyst in a young child. Pediatr Dent. 2000;22:422-3.

41. Flaitz CM, Davis SE. Oral and maxillofacial pathology case of the month. Oral lymphoepithelial cyst. Tex Dent J. 2004;121:624, 30-1.

42. Iwase T, Teratani K, Saito A, Funatsu K, Sato M, Kiuchi K, et al. Immunohistochemical and lectin histochemical studies on the lymphoepithelial cyst of the oral cavity and neck. J Nihon Univ Sch Dent. 1985;27:28-34.

43. Kumara GR, Gillgrass TJ, Bridgman JB. A lymphoepithelial cyst (branchial cyst) in the floor of the mouth. N Z Dent J. 1995;91:14-5.

44. Merchant NE. Lymphoepithelial cyst of the floor of the mouth: a case report. . Br Dent J. 1972;132:271-2.

45. Pereira KM, Nonaka CF, Santos PP, Medeiros AM, Galvao HC. Unusual coexistence of oral lymphoepithelial cyst and benign migratory glossitis. Braz J Otorhinolaryngol. 2009;75:318.

46. Sakoda S, Kodama Y, Shiba R. Lymphoepithelial cyst of oral cavity. Report of a case and review of the literature. Int J Oral Surg. 1983;12:127-31.

47. Silva IH, Romanach MJ, Carvalho AT, de Almeida OP, Leao JC, Gueiros LA. Bilateral lymphoepithelial cyst of the tongue: a case report. Gen Dent. 2013;61:32-4.

48. Silva MMC AL, Soubhia AMP, Crivelini MM. Lymphoepithelial Cyst in Jugal Mucosa. Int J Odontostomat. 2011;5:55-8.

49. Stramandinoli-Zanicotti RT, de Castro Avila LF, de Azevedo Izidoro AC, Izidoro FA, Schussel JL. Lymphoepithelial cysts of oral mucosa: two cases in different regions. Bull Tokyo Dent Coll. 2012;53:1722.

50. Vieira EMMP VC, Semenoff TADV, Aranha AMF, Baratto-Filho F, Borges AH. Lymphoepithelial cyst in the palatoglossus arch. Revista Cubana Estomatología. 2012;49:335-40.

51. Yamamoto H, Fukumoto M, Matsumoto T, Gunge M, Otake S. An immunohistochemical study of a lymphoepithelial cyst occurring on the ventral surface of the tongue. J Nihon Univ Sch Dent. 1987;29:206-10.

52. Young WG, Claman SM. A lymphoepithelial cyst of the oral cavity. Report of a case. Oral Surg Oral Med Oral Pathol. 1967;23:62-70.

53. Toto PD, Wortel JP, Joseph G. Lymphoepithelial cysts and associated immunoglobulins. Oral Surg Oral Med Oral Pathol. 1982;54:5965 .

54. Chaudhry AP, Yamane GM, Scharlock SE, SunderRaj M, Jain R. A clinico-pathological study of intraoral lymphoepithelial cysts. J Oral Med. 1984;39:79-84.
55. Vickers RA, von der Muhll OH. An investigation concerning inducibility of lymphoepiethelial cysts in hamsters by autogenous epithelial transplantation. J Dent Res. 1966;45:1029-32.

\section{Conflict of Interest}

None declared. 